\section{Civil Society and the Democratic Peace}

\section{Håvard Hegre ${ }^{1,2} \oplus$, Michael Bernhard ${ }^{3}$, and Jan Teorell ${ }^{4}$}

Journal of Conflict Resolution 2020, Vol. 64(I) 32-62 (C) The Author(s) 2019

Article reuse guidelines: sagepub.com/journals-permissions DOI: 10.1 I77/00220027/9850620 journals.sagepub.com/home/jcr

@SAGE

\begin{abstract}
We theorize that three distinct structures of democratic constraint explain why more democratic dyads do not engage in military conflict with each other. We build on earlier theories that focused on electoral and horizontal accountability. We add a new dimension - the social accountability provided by an active civil society. Using several new measures from the Varieties of Democracy (V-Dem) data set, we stringently test these explanations. We find social accountability to be the strongest and most consistent predictor of nonbelligerence in dyads, that horizontal accountability is still important, but that the independent role of electoral accountability has been somewhat overstated. However, we do find that social and electoral accountability work strongly together, to make for an even greater effect. The finding is robust to a range of specifications and in the face of controls for contending theories that challenge the democratic peace (e.g., the capitalist and territorial peace theories).
\end{abstract}

\title{
Keywords
}

democratic peace, interstate conflict, democratic institutions, dyadic conflict

\footnotetext{
'Department of Peace and Conflict Research, Uppsala University, Uppsala, Sweden

${ }^{2}$ Peace Research Institute Oslo (PRIO), Oslo, Norway

${ }^{3}$ Department of Political Science, University of Florida, Gainesville, FL, USA

${ }^{4}$ Department of Political Science, Lund University, Lund, Sweden
}

\section{Corresponding Author:}

Håvard Hegre, Department of Peace and Conflict Research, Uppsala University, Uppsala 75I2I, Sweden.

Email: havard.hegre@pcr.uu.se 
The democratic peace has proved to be one of the most influential and durable findings in the history of international relations, if not political science as a whole. As with all influential findings, alternatives have been posed, for example, the "capitalist peace" (Gartzke 2007; Mousseau 2000, 2009, 2013), the "territorial peace" (Gibler 2012), or "political similarity" (Bennett 2006; Raknerud and Hegre 1997; Peceny, Beer, and Sanchez-Terry 2002; Werner 2000). Beyond such empirical challenges, the finding has also been criticized for not providing a fully convincing causal logic that explains the empirical finding (Rosato 2003). This puzzle of what makes democracies less likely to engage in conflict with other democracies still remains subject to a lively and inconclusive debate (Hegre 2014). Our purpose here is to use the new Varieties of Democracy (V-Dem) data, with its ability to more precisely disaggregate the components of democracy, to reconsider its causal logic in a more precise fashion and with a fresh perspective.

We advance the debate by arguing that different forms of constraint on power holders help to explain why democratic dyads are less likely to engage in conflict. To date, the greatest attention has been focused on what we term electoral and horizontal accountability. Electoral accountability (sometimes referred to as vertical accountability) functions because elected politicians try to avoid alienating voters in anticipation of the next round of elections. Horizontal accountability operates through the ability of other branches of government and state institutions to check the power of the executive. We build on previous work that showed that greater electoral participation (Reiter and Tillman 2002; Clark and Nordstrom 2005; Bueno de Mesquita et al. 1999) and greater horizontal constraints on the executive (Reiter and Tillman 2002; Clark and Nordstrom 2005; Choi 2010) work to reduce conflict. An important part of our contribution is to add a new dimension-social accountability. It is provided by organized actors in civil society that have the ability to inflict audience costs on the executive in-between elections and to mobilize in support of opponents during elections.

We also highlight a new measurement tool for capturing democracy as an aggregate and in its component parts in new and potentially fruitful ways. Whereas the vast majority of studies have relied on Polity to capture the degree of democracy among states, we use the V-Dem data, which have both better concept-measurement consistency and also allow us, because of the ability to disaggregate components of democracy, to directly test the different forms of constraint we discussed above. Our sample includes observations from 173 countries across the globe from 1900 to 2010. We test whether these three different forms of accountability-(1) horizontal, (2) electoral, and (3) social-restrain democracies from fighting with each other. When pitting the three mechanisms of accountability directly against each other, we find the weakest support for the form that has received the greatest attention in the literature-electoral. However, its effect becomes salient when it is combined with social accountability between elections. The democratic peace effect thus seems less a product of simple electoral constraint than on the ability of civil society, as well as other state actors, to constrain the incumbent. To our knowledge, this is the first time 
that anyone has tested the impact of civil society engagement on conflict behavior. In an Online Supplementary File (henceforth SF), ${ }^{1}$ we demonstrate that our main findings are robust in the face of contending theories and alternate specifications of our tests.

\section{Retheorizing the Structural Mechanisms Behind the Democratic Peace}

We choose not to pursue the previous approach of pitting "normative" against "structural" explanations for the democratic peace (Maoz and Russett 1993). ${ }^{2}$ Since structural constraints will have normative (or cultural) implications, we believe these two theories cannot be fruitfully tested against each other given the limited temporal and geographic scope of behavioral data. Furthermore, we agree that it is difficult to distinguish them empirically because "norms of reciprocation and compromise" over time become embedded in "regulated political competition" blurring the distinction between the two (Maoz and Russett 1993, 625). We instead approach the problem in an explicitly structural fashion.

Structural explanations start from the assumption that "international action in a democratic political system... requires the mobilization of both general public opinion and of a variety of institutions that make up the system of government, such as the legislature, the political bureaucracies, and key interest groups" (Maoz and Russett 1993, 626). Democratic leaders, then, must formulate policies that reflect the interests of citizens and powerful organizations. If not, they face the prospect of removal from office (Bueno de Mesquita, Siverson, and Woller 1992; Bueno de Mesquita et al. 1999). Moreover, debate is public and decision-making is formalized so that decisions are taken at least in part on the basis of high-quality, comprehensive information on the potential costs of action. As a result, "[Democratic leaders] will not fear attack by another democracy. They will also know that institutional constraints, and the need for public debate in the other democracy, will prevent a surprise attack and so eliminate their own incentives to launch a preemptive strike" (Ember, Ember, and Russett 1992, 576-77; also see Schweller 1992).

The ability of democracies to signal their intentions reinforces structural constraints. Fearon (1995) argues that if crisis escalation does not cost much, both states will exaggerate their power or resolve to negotiate a better deal. If this bluff is discovered, they can simply back down later. "Audience costs," however, lock leaders into their positions, increasing reputational costs if they are caught bluffing (Fearon 1994). As democratic states have higher audience costs, they are more likely to credibly commit to policies that signal their true intentions and thus avoid the kind of escalation that promotes crises (Choi 2010). ${ }^{3}$

We understand accountability as the ability of actors to oblige power holders to inform the public about their activities and to justify them (Schedler 1999), as well as to sanction them, i.e. to impose costs in response to unwanted behavior (Lindberg 2013). We examine both horizontal and electoral accountability in their 
conventional forms as critical elements of well-functioning democracy (O'Donnell 1998), but we also look at social forms of accountability absent from this literature.

We thus move beyond the commonplace understanding of accountability in the literature on the democratic peace that stresses elections as the means by which populations hold leaders accountable. Given that elections are periodic, there remains the question of what makes accountability work between them (Przeworski, Stokes, and Manin 1999). In democracies in which electoral accountability is not supported by other accountability mechanisms, rulers can develop the ability to govern unconstrained by the preferences of citizens who elect them (O'Donnell 1994). The constraints posed by electoral accountability work best when they include complementary mechanisms that reinforce costs between elections. If the impact of democracy on conflict is uniform across electoral cycles, then we should be able to identify the mechanisms that make it effective between elections.

We examine the effects of three distinct accountability mechanisms-through institutionalized elections by which citizens may vote incumbents out of power (electoral), through the checks and balances between different state institutions (horizontal), and through the costs imposed by protests, publicity, withdrawal of support, and other forms of activism by organized groups in civil society (social). It is the inclusion of this third mechanism and the finding that this dimension is an important contributor to the conflict-adverse behavior of democracies that makes our contribution to this literature unique.

\section{Electoral Accountability}

We begin with electoral accountability, how the reiterated regular and competitive election of leaders creates responsiveness to the concerns of the citizenry. Kant ([1795] 1991) argued that the citizens of a (democratic) republic would think twice before plunging into a war, for "this would mean calling down on themselves all the miseries of war" (p. 100). Insensitivity to citizens' preferences leads to sanctions by voters in the next round of elections, and this promotes the accountability of elected officials to the electorate. The logic of this form of accountability is captured by Przeworski, Stokes, and Manin (1999, 10):

\footnotetext{
Governments are "accountable" if citizens can discern representative from unrepresentative governments and can sanction them appropriately, retaining in office those incumbents who perform well and ousting from office those who do not .... Elections are a "contingent renewal" accountability mechanism, where the sanctions are to extend or not to extend the government's tenure.
}

This mechanism is a product of the relationship between leaders and the electorate. To examine this potential causal linkage, we draw on democratic theory evolving from Schumpeter's ([1942] 2003) classic and minimalist definition and updated versions that incorporate the critical dimension of suffrage (Munck 2009). 
According to this, the essence of electoral democracy is to make rulers responsive to citizens via regularly held elections, whose competitiveness are guaranteed by a basket of minimal political rights. ${ }^{4}$

The institutional explanations of the democratic peace most commonly refer to this electoral component or some version of it. Leaders who conduct risky and unsuccessful international policies should be removed from office by the voters (Bueno de Mesquita, Siverson, and Woller 1992; Fearon 1994). This requires that "there are regular opportunities for democratic publics to remove elites who have not acted in their interests" (Rosato 2003, 587).

We have strong theoretical expectations in this regard that will guide our testing strategy. Knowing that universal suffrage, as well as the introduction of nominal executive elections or presidential plebiscites, has been widely practiced in singleparty and even personalist dictatorships with rigged elections and strong state repression (Hermet, Rose, and Rouquie 1978), we deduce that only those elements present in democracy and absent in plebiscitary dictatorship should explain the democratic peace - namely free and fair elections under multiparty competition.

\section{Horizontal Accountability}

The second mechanism we explore, horizontal accountability, has received less attention. According to O'Donnell $(1998,117)$, “This kind of accountability depends on the existence of state agencies that are legally empowered - and factually willing and able - to take actions ranging from routine oversight to criminal sanctions or impeachment in relation to possibly unlawful actions or omissions by other agencies of the state." Merkel $(2004,41)$ elaborates on this form of accountability as a set of reciprocal checks between the executive, legislature, and judicial organs that respects the constitutional responsibilities of each but constrains their actions to those which they are lawfully empowered. The existence of horizontal accountability promotes self-enforcing equilibria in democratic systems as actors are compelled to abide by the rules of the game. In practice, this is primarily achieved through effective legislative and judicial checks on executive power. Strong constraints on the executive ensure that decision-making takes time and that the real costs of belligerent policies are (at least better) taken into account.

This conception featured in Doyle's (1986) influential argument about the "liberal peace" as well as in other explanations of the democratic peace such as in Ember, Ember, and Russett (1992) and Choi's (2010) application of legislative veto player theory. Such liberal peace arguments imply that it is the horizontal accountability between key governmental institutions that matters for peace.

\section{Social Accountability}

The third mechanism we highlight is social accountability, a mechanism that has not figured strongly in democratic peace theory. These are mechanisms by which citizen 
engagement can impose audience costs on leaders between elections, either directly or in anticipation of them. ${ }^{5}$ Here we draw inspiration from participatory notions of democracy (Pateman 1970; Macpherson 1977; Barber 1984; Gould 1988). This tradition emphasizes citizen engagement and nonelectoral forms of political participation through engagement in civil society organizations (CSOs; both advocacy and protest).

Civil society reemerged as a concept in the social sciences in the 1980 s to describe social mobilization and organization directed against authoritarian regimes in the literature on democratization (Arato [1981] 1993; Stepan 1985; and O'Donnell and Schmitter 1986). It also figured in the political culture literature as the institutional agent that creates the trust and social capital central to democracy (Putnam 1993; Edwards and Foley 1999; Welzel, Inglehart, and Deutsch 2005). In the former, a contentious civil society will challenge, constrain, and even overturn leaders and regimes. In the latter, it serves as the means by which organized interests articulate their demands to the political system, connecting citizens to elites and cultivating responsive behavior and democratic norms.

The accountability provided by regular elections operates unevenly over time even when it is effective. Social accountability works independently of electoral timing. This informal dimension keeps politicians focused on how their actions affect the organized citizenry between elections. The interest advocacy practiced by CSOs is seen as a more direct form of representation which supplements and may even supplant elected representation in promoting accountability (Fung and Wright 2003; Dalton, Scarrow, and Cain 2003; Chalmers, Martin, and Pister 1997; Houtzager and Lavalle 2010).

An organizationally developed and active civil society provides citizens with a range of nonelectoral means beyond voting to constrain leaders and the political establishment in war-related decisions. Civil society participation disposes elites to commit to the transparent signaling of intentions that avoids the misunderstandings in dyadic contexts that lead to crisis escalation and conflict (Fearon 1994). This works in a number of distinct ways.

First, pressure on the political system is enhanced by periodic bursts of civil society-led protest that highlight controversial issues, unpopular actions, and contentious policies, putting leaders on the spot, forcing them to focus on the issues of concern to the public (McAdam and Tarrow 2010; Ekiert and Kubik 1999). This forces them to build consensus around policies. Contentious actions directed against their policy can cut into their base of support, both for their own reelection, as well as that of the legislative majorities they need to organize to realize their policy agenda. The influence of domestic actors can also be enhanced by international support and global media coverage when their struggles have international relevance (Keck and Sikkink 1998).

Second, CSOs provide citizen-based monitoring and oversight of government agencies and officials (Smulovitz and Peruzzotti 2000, 152-53). They may publicize actions, policy proposals, and outcomes they oppose or find troubling, either through 
their own networks of supporters and activists or through mass media. They thus play a role in keeping the public informed about the actions of their government. The disclosure of previously concealed information can lead to rapid change in public opinion and ever undermine support in sitting governments (Kuran 1991; Lohmann 1994).

Finally, civil society activists have the ability to directly intervene in the operation of the government, reinforcing existing channels of horizontal accountability. Such activities include participation in public fora, engaging with the bureaucracy to secure desired outcomes, signing of petitions designed to force bureaucracy to fulfill its responsibilities, filing litigation in the courts to affect policy outcomes, as well as symbolic and disruptive actions (Cornell and Grimes 2015). In countries where there is legislation allowing for popular initiatives, such measures can be put directly on the ballot, bypassing the agenda-setting powers of executives and legislatures (Altman 2010).

While we argue that social accountability is powerful in itself, we expect that it will also reinforce electoral accountability. Social accountability forces ruling incumbents to consider their popular support in a more long-run perspective, outside of the electoral cycle. They have to worry that loss of policy support will translate into the alienation of supporters, whether that is in their party, among the organized interests that support their party, or from the social constituencies from which they draw their electoral support.

Conversely, the basket of civil and political rights that promote free and fair elections should make the exercise of influence by civil society more effective (Grimes 2013). Effective protest requires freedom of association. Alternative information is promoted by freedom of expression and the press. The use of litigation to challenge the government is enhanced by the degree to which there is rule of law and judicial independence. While it is clear that such freedoms may sometimes privilege the voices of better organized and resourced interests, the range of interests and concerns expressed in democratic systems far outstrips that under authoritarian systems.

The question remains whether civil society can be an effective actor in authoritarian contexts. The answer here, we believe, is dependent on how repressive is the particular form of authoritarianism. To the extent that the regime monopolizes social organization or constrains it through law or repression, this will make civil society less effective in creating audience costs. If the flow of information in the public space is constrained through censorship and the dominance of state mass media, then the ability to organize and educate the public will be reduced. If rule of law is weak and the courts are beholden to the regime, the ability to use litigation to contest state policy will be marginal.

Thus, we would expect different forms of authoritarianism to be more prone to the effects of civil society activism. An electoral authoritarian regime that engages in forms of manipulation that make elections less than fully free and fair, but formally recognizes a full basket of political and civil rights, will be much more prone to 
Table I. Mechanisms of Democratic Accountability and How They Potentially Explain the Democratic Peace.

\begin{tabular}{|c|c|}
\hline Mechanism & Causal Pathway \\
\hline $\begin{array}{l}\text { I. Electoral accountability via free } \\
\text { and fair competition }\end{array}$ & $\begin{array}{l}\text { Elected executive under conditions of clean, multiparty } \\
\text { elections, and universal suffrage } \rightarrow \text { government } \\
\text { responsiveness to popular preferences via potential } \\
\text { audience costs }\end{array}$ \\
\hline $\begin{array}{l}\text { 2. Horizontal accountability via } \\
\text { countervailing powers }\end{array}$ & $\begin{array}{l}\text { Judicial and legislative constraints on the executive } \rightarrow \\
\text { constraints on arbitrary exercise of executive power }\end{array}$ \\
\hline $\begin{array}{l}\text { 3. Social accountability via civil } \\
\text { society activism }\end{array}$ & $\begin{array}{l}\text { Activism by civil society organizations (advocacy, protest, } \\
\text { monitoring) } \rightarrow \text { government responsiveness to popular } \\
\text { preferences via potential audience costs }\end{array}$ \\
\hline
\end{tabular}

social accountability, than a totalitarian regime that places all forms of social organization under the control of the ruling party, monopolizes mass media through the state, and holds plebiscitary elections with one list composed of party-approved members. We also know that both electoral and conventional forms of authoritarianism that permit a degree of civil society autonomy also work to diminish that autonomy from the state through manipulation of information, subsidization of progovernment organizations, ${ }^{6}$ and selective repression of independent voices (Robertson 2011; Weiss 2014). For this reason, we would expect civil society actors to be less effective in constraining rulers in authoritarian contexts than in democracies. We fully expect the measure we use (see below) to effectively pick up these differences.

To take stock of our theory to this point, Table 1 summarizes the ways in which we argue that the three different accountability mechanisms tap into different causal logics that plausibly explain the connection between democracy and conflict.

We now proceed to competitively test these three accountability mechanisms to understand their relative weight in providing the kind of constraint that undergirds structural explanations of the democratic peace. In contrast to the existing literature, we suspect the role of electoral accountability has been overplayed. At the same time, we expect to find that informal paths of social accountability are much more important than realized and that their exclusion has obscured an important facet of the logic of the democratic peace. Specifically, we believe that effective electoral accountability is dependent on the ability of social accountability to hold rulers responsible between elections.

\section{Research Design}

Our research design is patterned on that of Hegre, Oneal, and Russett (2010) which is quite typical of many studies on the democratic peace. Formulating the dyadic 
nature of the democratic peace is not straightforward. As argued in Hegre $(2009,30)$, there is a fundamental problem with the weak-link procedure first developed by Dixon (1994). In many cases, the two countries in the dyad have lower values on different potentially constraining variables, making it difficult to identify which of the two countries is less constrained. We use the weak-link procedure proposed in Hegre (2008) that assumes that the strongest country in the dyad (in terms of military capabilities) always is the one that is "least constrained." We refer to this country as country $i$ and the weaker as $j$. We then enter the democracy score for the stronger country in the pair (called country $i$ ), that of the weaker country $(j)$, and the multiplicative interaction term between the two $(i j)$. If the dyadic democratic peace holds, the interaction term should be negative - the risk of interstate militarized conflict decreases as both countries become more democratic. We use this procedure for the control variables as well.

\section{Dependent Variable: Fatal Militarized Interstate Disputes (MIDs)}

The dependent variable is the onset of "fatal MIDs" - militarized interstate disputes that cause the death of at least one person. We use the MID v4.1 (Palmer et al. 2015) to extend the dyadic MID data set (Maoz 2005) up to 2010. In combination with the V-Dem data, this allows us to study the 1900 to 2010 time period.

\section{Main Independent Variables}

Due to its broad time coverage, the vast majority of studies on the democratic peace since Bremer (1992) have relied on the Polity data set to operationalize the concept of democracy. ${ }^{7}$ Polity has to some extent been amenable to disaggregating certain aspects of democracy to examine which of its properties are responsible for the pacific nature of democratic dyads. Choi (2013) for example has used it effectively to show that one prominent component, executive constraint (xconst), is a potential cause. However, Polity is not particularly fruitful for more fine-grained disaggregation that will allow us to pinpoint the ways in which political accountability works to enhance peace. ${ }^{8}$

In this article, we utilize the V-Dem data (Coppedge et al. 2016b; Lindberg et al. 2014) because of its explicit measurement of the features of democracy that we argue allow members of the elite embedded in countervailing centers of institutional power and the citizenry to constrain decision makers. While not until very recently as extensive over time as Polity, ${ }^{9}$ the V-Dem version (v6.2) we employ covers 173 different countries since 1900 and has an unprecedented conceptual depth that allows for democracy to be considered as a variety of aggregates and to examine the effect of its component parts.

V-Dem collects data by leveraging the knowledge of country experts, mostly local academics who are asked to make discrete judgments by choosing from a number of well-defined categorical responses. The questionnaire consists of eleven 
different batteries, and coders are asked to work only on their areas of expertise. The vast majority of individual country-year indicators are coded by an average of over five experts (involving all in all more than 2,600 experts). These individual ratings are used to generate point estimates using a Bayesian item response theory (IRT) measurement model (see Pemstein et al. 2015). In order to enhance the comparability of estimates cross-nationally, the coding procedure makes use of "lateral coders" who rate a few countries for a shorter time period and "bridge coders" who rate more than one country for all country years (Coppedge et al. 2016c). The measurement model thereby produces latent variable estimates, which takes account of variation in rater thresholds and estimates of coder reliability (precision).

In this article, we will primarily draw on three different indices of constraint, one for electoral accountability (also decomposed into one subindex and one indicator), one for horizontal accountability, and one for social accountability. Except for the latter, these are not off-the-shelf indices part of the V-Dem package but were tailored for the specific theoretical purposes of this article.

Electoral accountability. Following Munck (2009), this is an index of electoral accountability based on four components: (1) an elected executive (v2x_accex, a multiplicative index based on twelve factual indicators), (2) clean elections (v2xel_frefair, a Bayesian factor analysis [BFA] index based on eight expertcoded indicators), (3) multiparty elections (v2x_multiparty, a BFA index based on four expert-coded indicators), and (4) universal suffrage (v2x_suffr, which is a single factual indicator). ${ }^{10}$ To capture the notion that each of these components is a necessary condition, and that the overall level of electoral accountability works as a chain defined by its weakest link, the four components are aggregated into an overall index through multiplication (v2x_munck). In order to tease out the extent to which suffrage plays an independent role in explaining the democratic peace, we also rely on an index based on only the first three components. This index more closely follows Schumpeter's ([1942] 2003) influential minimalist definition of democracy, where suffrage is omitted from the definition. When this Schumpeterian index of electoral accountability is used, we control separately for the extension of the suffrage.

We construct three variables from the electoral accountability index: (1) electoral accountability $_{i}$ is the index for the stronger country in the dyad, (2) electoral accountability $_{j}$ for the weaker, and (3) electoral accountability ${ }_{i j}$ is the product of electoral accountability and $_{i}$ electoral accountability. All indices are scaled to range from zero to one. We make similar constructions from the other countrylevel variables.

Horizontal accountability. This index measures the existence of countervailing powers that check the exercise of executive power. It is the average of the expert-coded VDem indicators for legislative (v2x_legcon) and judicial (v2x_jucon) constraints on the executive. Both are based on the point estimates from Bayesian factor analysis 
models of V-Dem indicators. The legislative constraints index taps into (a) the extent to which the legislature questions officials in practice, (b) exercises executive oversight, (c) investigates the executive in practice, and (d) investigates whether the opposition in the legislature is able to exercise oversight and investigatory functions against the wishes of the governing party or coalition. ${ }^{11}$ The judicial constraints are based on (a) whether the executive respects the constitution and whether the executive complies with important decisions of both (b) the high court and (c) lower courts with which it disagrees as well as how often the (d) high court and (e) lower courts make decisions that merely reflect government wishes regardless of its sincere view of the legal record (judicial independence). ${ }^{12}$

Social accountability. Social accountability is operationalized using an off-the-shelf VDem measure - the civil society participation index (v2x_cpart) which gauges the level of activism by CSOs. CSOs "include, but are by no means limited to, interest groups, labor unions, spiritual organizations (if they are engaged in civic or political activities), social movements, professional associations, charities, and other nongovernmental organizations" (Coppedge et al. 2016a, 56-57). The index of civil society participation is formed by taking the point estimates from a Bayesian factor analysis model of the indicators tapping into (a) whether civil society influences legislative candidate nomination within party organization through decentralization or party primaries, (b) whether major CSOs are routinely consulted by policymakers, (c) how extensive is the involvement of citizens in the network of CSOs, and (d) women's participation in CSOs. ${ }^{13}$

Mapping constraint. The indicators of constraint are highly correlated with each other. For the year 2010, the indicators are correlated at 0.77 or higher (see Figure SF-1). ${ }^{14}$ In 2010, the social accountability index is somewhat distinct from the other two. The scatterplots in Figure 1 show how social accountability index relates to the electoral accountability index (left) and the horizontal accountability index (right).

Longstanding, consolidated democracies typically have high values for all these indicators, for example, Great Britain (GBR) or Italy (ITA). Clearly, authoritarian regimes such as Cuba (CUB) or Qatar (QAT) have low values for each. A large number of emerging or troubled democracies display much more heterogeneous patterns of constraint. Countries like Venezuela (VEN), Guyana (GUY), and Ecuador (ECU) have relatively weak constraints on the executive compared to electoral accountability. Other countries, such as Iran (IRN), Kenya (KEN), and Tanzania (TAZ), have strong checks on executive power. Civil society participation differs from electoral accountability following a different pattern. It is clearly weakest in those political systems that have almost no electoral accountability, such as in North Korea (PRK) and Turkmenistan (TKM). Noncompetitive electoral systems, such as Morocco (MAR) and Vietnam (VNM), are less repressive of civil society. Among those countries with higher levels of electoral accountability, there is considerable 


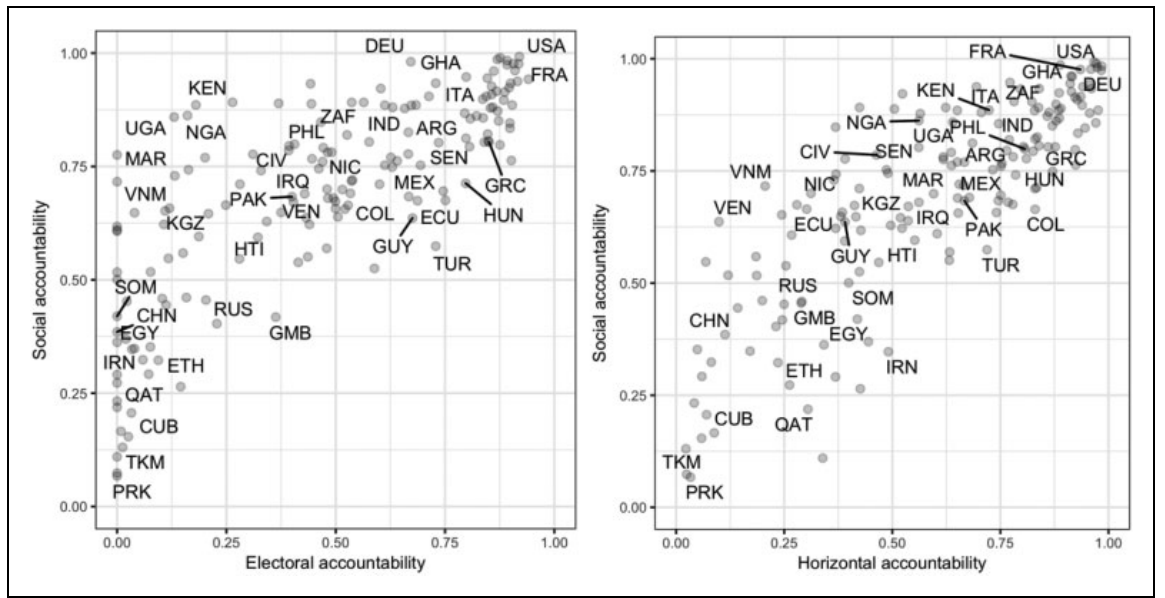

Figure I. Scatterplot of social accountability index versus electoral accountability index (left) and horizontal accountability index (right), 2010.

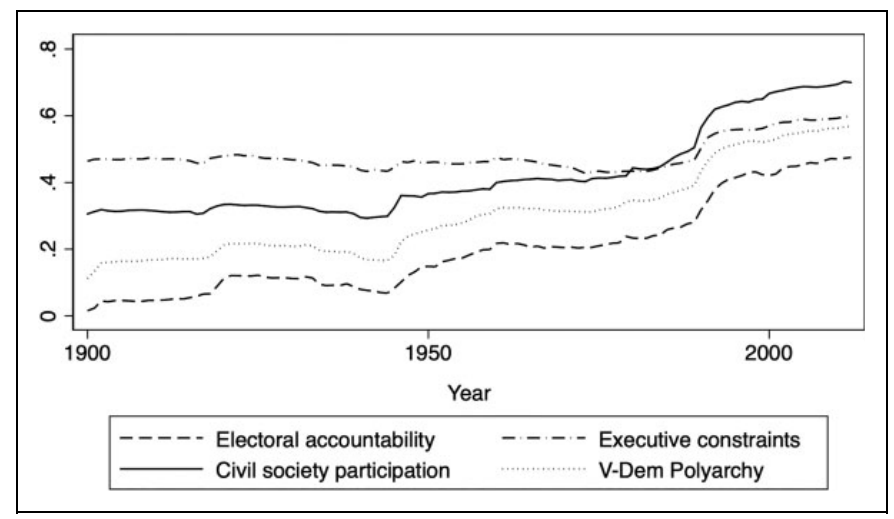

Figure 2. Global trends in the three indices of constraint and the Varieties of Democracy (V-Dem) Polyarchy index, 1900 to 2012. Nonweighted country averages.

variation in how participatory civil society is. Ghana (GHA), for instance, scores much higher than Turkey (TUR) in 2010.

Figure 2 shows global trends in the constraint indices, demonstrating another set of differences between them. The (unweighted) global average electoral accountability index increased steadily from close to 0 to about 0.4 as political liberties were extended in most countries in the world. As the trend line for V-Dem's Polyarchy index makes clear, our electoral accountability index is more demanding (always falls below), which is a product of both the exclusion of freedom of expression and 
the purely multiplicative aggregation rule. Social accountability also increased steadily throughout the twentieth century and beyond. Horizontal accountability, on the other hand, changed little from 1900 up to the collapse of the Soviet Union in $1990 .^{15}$ All indices have increased markedly after the end of the Cold War and have increased in parallel over the past twenty-five years. If the democratic peace depends mostly on the electoral and social accountability mechanisms, Figure 2 indicates that it has strengthened considerably over the past century. If it draws strength mainly from the horizontal accountability mechanism, this deepening occurred mainly after the Cold War.

\section{Other Variables}

Polity. For comparison, we also present results in the SF using the Polity data set (Marshall 2014). The V-Dem Polyarchy index and the Polity2 index are highly correlated (at about 0.84 ) but differ in some important respects. In general, the VDem index displays a stronger increasing trend over time than Polity, in part since it reflects the extension of suffrage much better than Polity. ${ }^{16}$

The remaining variables in the model extend to cover 2002 to 2010 the replication data set of Hegre (2008). We include the Composite Index of National Capability (CINC score; Singer, Bremer, and Stuckey 1972) for the stronger and weaker country, population size for the stronger and weaker, direct contiguity, distance between states, system size (Raknerud and Hegre 1997), and a decay function of the number of peace years in the dyad to account for temporal dependence. All these variables are described in detail in the SF.

\section{Results}

\section{Main Specifications}

We estimated two sets of models for all pairs of states for every year over the 1900 to 2010 period with the democratic peace hypothesis represented as the democracy score(s) of the stronger country, that of the weaker country, the interaction of these two, and several control variables. In the first set of models, we entered the five indicators of constraint one by one along with our control variables. Figure 3 summarizes the results from these models. Complete estimation results in table form with all control variables are found in Table SF-3.

The first model (called electoral accountability) enters the electoral accountability index scores of both members of the dyad and their interaction along with control variables. The estimates from this model are printed in black color at the top of the figure. The points represent the estimates and the whiskers their $95 \%$ confidence interval. The two main terms are both positive, although for the weaker country it is not statistically significant. The interaction between the index values for the two countries in the dyad, on the other hand, is negative and highly significant - when 


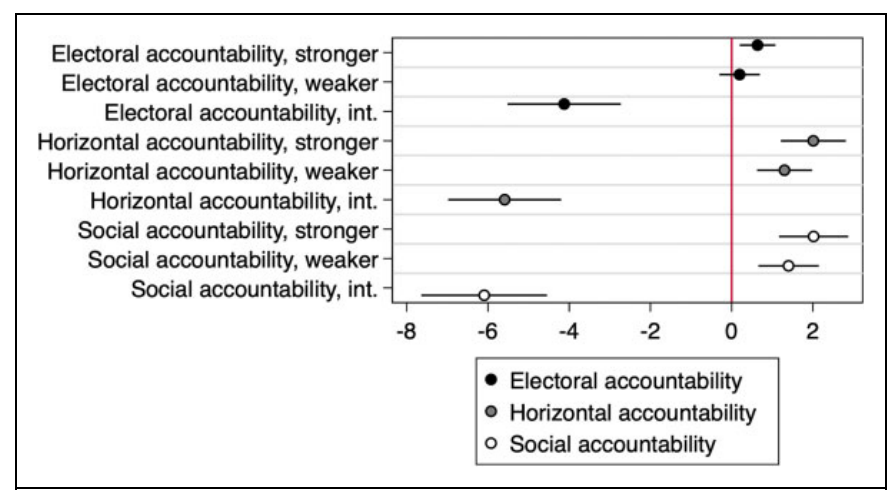

Figure 3. Coefficient estimates, models with the indices of constraint entered individually. Figure created using the Stata coefplot package (Jann 20I4). Complete estimates are reported in Table SF-3 (columns I-3).

both countries score highly in terms of electoral accountability, the risk of a fatal dispute is much lower than if either have low scores. In line with expectations, we show in Table SF-6 that the effect of electoral democracy is driven by the "Schumpeterian" core dimensions tapping into contestation-whereas suffrage does not play an independent role in promoting peace.

The second model enters the horizontal accountability terms. The third model adds the social accountability variables to the controls. In both of these models, the interaction terms are negative and significant, whereas the main terms are positive and significant. Each of the three sets of individual indices are related similarly to interstate peace.

Figure 4 shows that the net effect for each of these indicators is consistent with the democratic peace. In the left panels, the dashed line plots the estimated log odds of a MID when the weaker country $j$ is at the mean of the index, as a function of the score for the stronger country (along the $x$-axis). The metric for the $y$-axis is log odds relative to the case where both countries have scores of 0 for the index. The dotted and solid lines show the same when the index is one standard deviation below or above the mean. ${ }^{17}$

The graph on the right plots the marginal effect of this relationship - it shows the change in the estimated probability of a fatal dispute when comparing a pair of countries where the weaker country has a value for the index one standard deviation below the mean and one standard deviation above, respectively, as a function of the index for the stronger country. Both these graphs show a clear dyadic democratic peace in terms of all our indices of constraint - a more democratic weaker country means a clearly lower risk of fatal MID if the stronger country is relatively democratic. $^{18}$ 


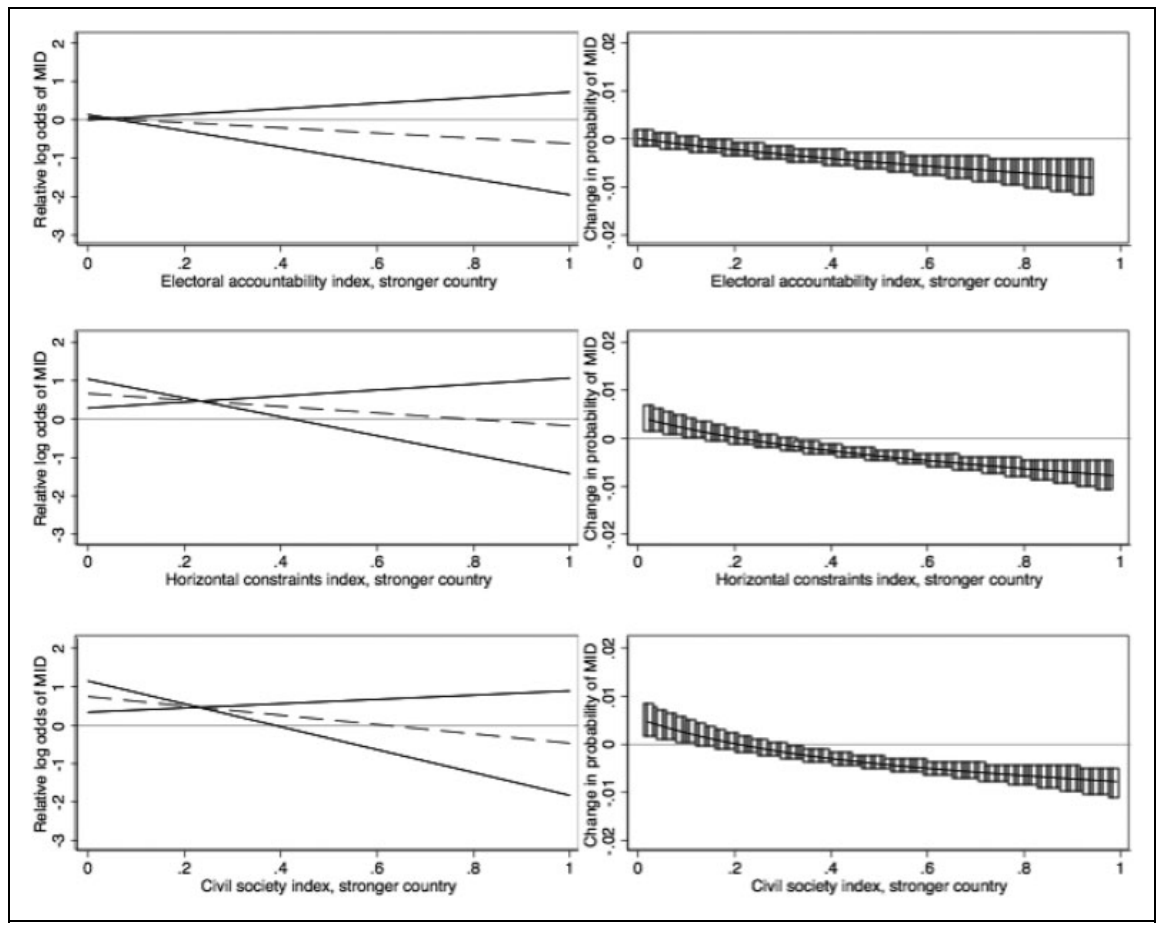

Figure 4. Risk of fatal MID as a function of the individual indicators of constraint. The figures to the left show estimated log odds of fatal MIDs as a function of the indicator value of the stronger country, varying the value for the weaker country. The dashed lines show this relationship when the relevant index for the weaker country is at the mean, the dotted lines when the index for the weaker country is one standard deviation below the mean, the solid lines when the index for the weaker country is one standard deviation above the mean. The figures to the right show the marginal effect of a two standard deviation increase in the indicator score of the weaker country as a function of the indicator value for the stronger county. Figures to the right were created using the intgph package (Zelner 2009; Tomz, Wittenberg, and King 2003). The figures are based on a data set where we reduce the size of the data set by removing at random $95 \%$ of the non-MID dyad years. Table SF- 8 shows that the reduced-sample results are very close to the full-sample ones.

All of our individual indicators of constraint reflect the democratic peace when entered on their own. Given the high correlation between them, we investigate their relative impact in two different ways. The first is to estimate models with all the individual terms entered simultaneously. In Figure 5, we show the results of a "joint constraint model" that contains all terms. ${ }^{19}$ The electoral accountability index terms are not distinguishable from zero in this model. It should be noted that this result cannot be explained by multicollinearity, since the variance inflation factor is not particularly higher for this index or its interaction effect. ${ }^{20}$ The horizontal 


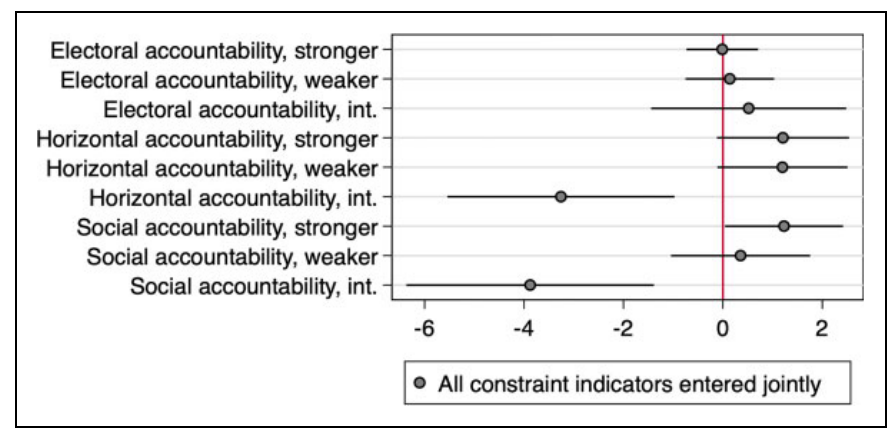

Figure 5. Coefficient estimates, models with the indices of constraint entered jointly. Figure created using the Stata coefplot package (Jann 20I4). Complete estimates for this model are reported in Supplementary Materials Table S-2 (column 4).

accountability variables, on the other hand, retain separate contributions to the democratic peace. The interaction term is negative and significant. The variable that retains the most of its impact on the probability of a fatal dispute is the social accountability index. The democratic peace seems to rest in particular on horizontal constraints on the executive and the presence of strong and active CSOs.

The second route is to compare the models in terms of their overall fit to the data. A set of different metrics is reported in Table 2 for the six models reported in Figures 3 and 5 as well as some additional models in Table SF-9. The Akaike information criterion (AIC) values for each model discussed so far are reported in the "AICfull" column. The civil society model has the lowest AIC values, indicating as above that this variable provides the best fit within the estimation sample. The table also reports how well the different models do in terms of out-of-sample predictive performance. $^{21}$ To obtain these estimates, we first reduced the size of our data set by removing at random $95 \%$ of all the non-MID dyad years. ${ }^{22}$ We then drew half of all dyads at random, estimated the models on this partition, obtained predictions for the nonestimation partition, and compared with the actual record of fatal MIDs for the nonestimation partition. We repeated this for twenty independently sampled divisions of the sample. The "AICds" column in Table 2 shows the average (in-sample) AICs for the twenty reduced-sample estimations. The "AUROC" and "Brier" columns show the area under the receiver operator curve and the Brier scores averaged over the twenty out-of-sample partitions. Models that predict well out of sample have high scores on the AUROC and low Brier scores. The two statistics indicate similar rankings of the models.

The out-of-sample evaluation of predictive performance further strengthens the impression that the electoral accountability mechanism is weaker than the other two. The AUROC is lower and the Brier is higher for this model than for the other models. The horizontal and social accountability models perform the best. The 
Table 2. Model Summary Statistics.

\begin{tabular}{lccccc}
\hline Model & AICfull & AICds & AUROC & Brier & $N$ \\
\hline Electoral accountability & $5,945.7$ & $1,567.67$ & .9372 & .01421 & 541,560 \\
Horizontal accountability & $5,873.3$ & $1,534.80$ & .9407 & .01386 & 541,560 \\
Social accountability & $5,854.5$ & $1,522.82$ & .9386 & .01388 & 541,560 \\
Joint constraint model & $5,848.0$ & $1,520.31$ & .9400 & .01383 & 541,560 \\
Social and electoral & $5,858.6$ & $1,531.96$ & .9380 & .01387 & 541,560 \\
Social-electoral interaction & $5,831.2$ & $1,510.45$ & .9414 & .01383 & 541,560 \\
Polity & $5,894.6$ & $1,544.88$ & .9409 & .01406 & 541,560 \\
Polyarchy & $5,885.3$ & $1,549.01$ & .9403 & .01408 & 541,560 \\
Liberal democracy & $5,852.3$ & $1,529.76$ & .9416 & .01391 & 541,560 \\
Participatory democracy & $5,882.6$ & $1,540.08$ & .9384 & .01399 & 541,560 \\
Deliberative democracy & $5,886.2$ & $1,552.34$ & .9412 & .01409 & 541,560 \\
Egalitarian democracy & $5,899.1$ & $1,543.20$ & .9381 & .01401 & 541,560 \\
Legislative constraint & $5,917.9$ & $1,549.37$ & .9388 & .01408 & 541,560 \\
Judicial constraint & $5,882.2$ & $1,536.02$ & .9400 & .01412 & 541,560 \\
Schumpeter & $5,916.4$ & $1,562.67$ & .9393 & .01413 & 541,560 \\
Lean civil society & $5,929.9$ & $1,559.42$ & .9357 & .01415 & 541,560 \\
\hline
\end{tabular}

model including all the three indicators performs considerably better than the three models in Figure 3 across all metrics, suggesting that the conclusions drawn from Figure 5 are still valid.

Figure 6 illustrates the implications of the joint constraint model compared to the electoral accountability only model for selected dyads in 2010. For each pair of countries, we calculated the extent to which "joint democraticness" in each alters the risk (measured as log odds) of conflict in comparison to what is explained by the control variables. We plot the marginal effect of the electoral accountability model along the horizontal axis and that of the joint constraint model along the vertical one. Democratic pairs such as Great Britain and India (IND-GBR) have a low risk of conflict according to both models and are located in the lower left corner. ${ }^{23}$ Pairs with one democracy and one nondemocracy such as Great Britain and North Korea (GBR-PRK) have a high risk and are found in the upper right. The diagonal line represents the case where the two models yield similar predicted effects.

The figure shows that models that reflect multiple dimensions of accountability give a more nuanced picture of interstate conflict risk. The electoral accountability model indicates that autocracies such as North Korea, Turkmenistan, and Myanmar have equally high risk of conflict with democracies. The joint constraint model distinguish much better between them-the predicted risk of conflict between GBR and North Korea is twice as high as between GBR and Myanmar. ${ }^{24}$

Our results suggest that the democratic peace rests less on electoral accountability than on horizontal and social constraint. Illiberal democracies, hybrid regimes, and electoral authoritarian regimes such as Turkey and Venezuela in 2010 continue to 


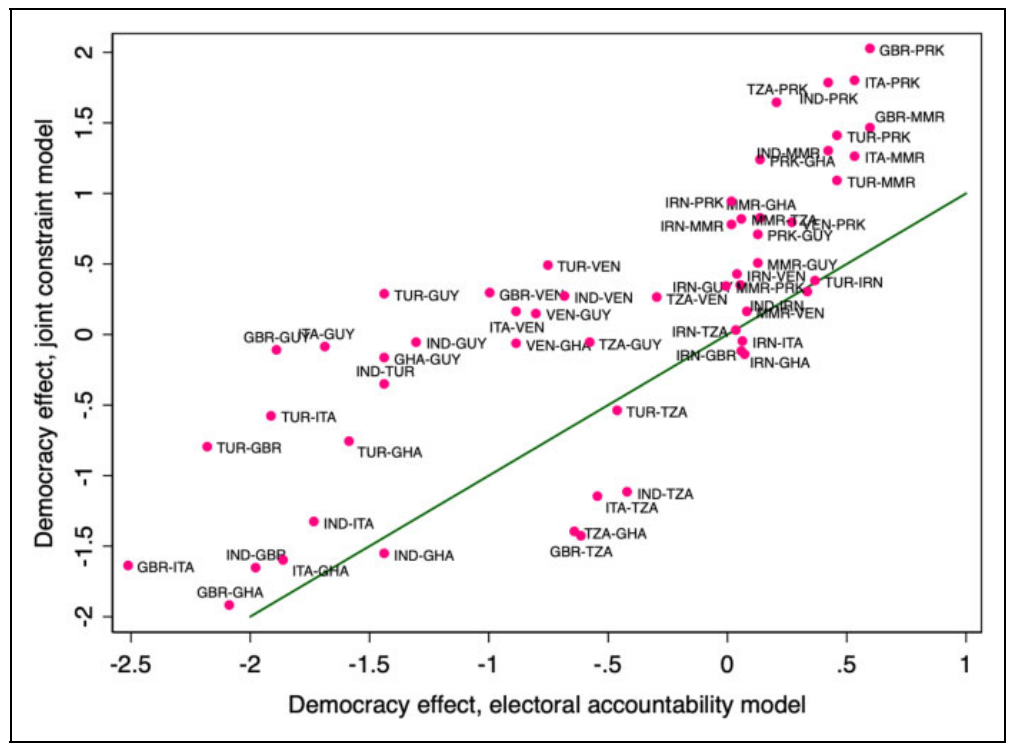

Figure 6. Predicted log odds of conflict derived from the "joint constraint model" compared to the electoral accountability only model, selected dyads, 2010 , control variables held constant. The figure shows how much the indices of constraint change the log odds of conflict for each dyad relative to what is predicted by the control variables in the model. The values along the $x$-axis are the sums $\beta_{1} x_{i}+\beta_{2} x_{j}+\beta_{3} x_{i j}$, where $x_{i}$ is the electoral accountability index value for country $i, x_{j}$ the value for country $j, x_{i j}$ the interaction term, and the $\beta$ terms the corresponding from the electoral accountability model. The values along the $y$-axis are constructed in a similar way for all the accountability terms in the joint constraint model.

hold competitive elections but harass CSOs and undermine horizontal constraints on their ambitious executives. The joint constraint model indicates that the pairs of countries they form are more bellicose than the electoral accountability model suggests. Figure 6 shows, for instance, that the electoral accountability index values for Turkey-Venezuela dyad ("TUR-VEN") translates into a reduced log odds of conflict of .7 relative to what is implied by the control variables. The combined effect of the joint constraint model is to increase log odds by 0.1 . The difference in the predictions from the two models is less marked for Venezuela than for Turkey however because V-Dem rates Venezuela as having a much stronger civil society in 2010 .

Similarly, a number of weaker at-risk democracies, such as Kenya or Tanzania, despite their low level of vertical electoral accountability should have a lower risk of conflict with other democracies than these two illiberal examples. Pairs of countries including Ghana or Tanzania, for instance, score relatively better on civil society participation than on electoral accountability. Figure 6 shows that these pairs have 
very low predicted risk of conflict by the joint constraint model but are placed close to the middle by the electoral model.

Our theoretical argument implies that social accountability should contribute to the democratic peace even in political systems where elections are absent or meaningless. However, it also suggests that electoral and social accountability reinforce each other. To explore this, we estimated a model with interaction terms between electoral and social accountability (see Table SF-4 for complete results). This model performs better in terms of in-sample and out-of-sample fit to data than all the other models (Table 2).

Figure 7 shows the interpretation of this interaction model. Both panels show estimated $\log$ odds of fatal MID as a function of electoral accountability in the stronger country, with separate lines for low (solid line), medium, and high (dashed line) electoral accountability in the weaker. The democratic peace implies that log odds is lowest when both countries have high accountability. The upper panel shows this relationship when social accountability is low for both countries. In that case, the estimates do not support the hypothesis that joint electoral accountability reduces the risk of conflict. The lower panel, on the other hand, shows the same when social accountability is high in both countries. Under these conditions, there is a clear "electoral peace." In addition, the figure shows that log odds of conflict is lower overall when social accountability is high.

By implication, the vast expansion of electoral accountability during the twentieth century demonstrated in Figure 2 may have considerably less positive implications for international peace than the steady improvement in all three indices of constraint seen from 1990 onward. Our analysis has important bearings for the "decline of war" thesis (Gat 2006; Pinker 2011; Gleditsch et al. 2013). After the end of the Cold War, the Uppsala Conflict Data Program (UCDP) records a much lower frequency of interstate wars than in preceding decades (Petterson and Eck 2018). Our analysis suggests that the strengthening of civil society participation and executive constraints are important contributors to this trend. ${ }^{25}$

\section{Robustness Tests}

The findings presented are very robust to alternative specifications. The SF contains the results from a range of other models that take into account various critiques of the democratic peace, as well as applying alternative designs.

For comparison, we estimated a set of models using the five standardized V-Dem indices of democracy as well as with the Polity index of democracy. The detailed results are reported in Table SF-9 and the model summary statistics in Table 2. The democratic peace is supported no matter which index we are using - the interaction term is negative and significant in each of them. The model summary statistics in Table 2 suggest each of them perform less well than our theoretically derived institutions of accountability, however. 


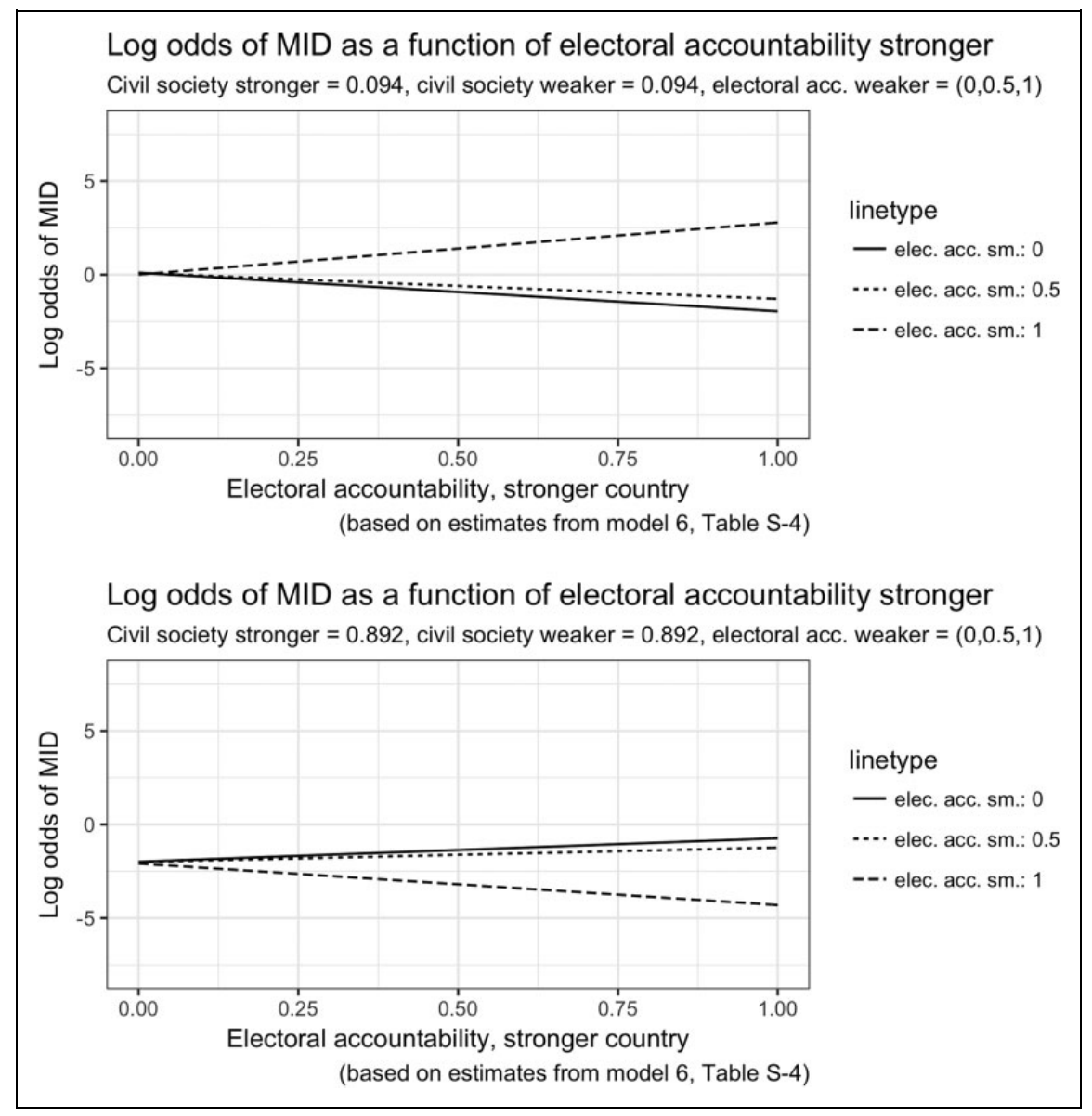

Figure 7. Predicted log odds of conflict relative to a nondemocratic baseline, as a function of electoral accountability stronger, control variables held constant. Social accountability index for both countries held at 10th (upper) and 90th (lower panel) percentiles.

Table 2 also reports the results from three models with alternative operationalizations of our indices of constraint. In the "Schumpeter" model, we use the minimalist measure described above, controlling for the extent of suffrage. This operationalization of the "electoral" democratic peace fits the data better than the more extensive one but still not as well as the horizontal and social variants. We also split the horizontal accountability index into its constituent parts (Table SF-7). The two subindices pull in the same direction, so the joint indicator makes for a more parsimonious and effective model. Finally, we estimate a model with a much leaner version of the civil society participation index, omitting information on civil society 
input on nominations, civil society consultation, and women's participation in CSOs (Table SF-6). The model using the lean civil society measure performs less well than our preferred corresponding metric but still better than the electoral accountability model.

Table SF-10 shows that our results hold up equally well with the traditional weaklink formulation. This analysis also shows that our specification fits the data much better than the traditional specification; its AIC scores are, in general, substantially lower. Table SF-6 shows the results also hold for wars leading to at least 1,000 deaths.

The SF also presents analyses that show that our results are robust to four major critiques and suggested extensions to the democratic peace. Adding simple time dummies and time trends and their interactions with our constraint variables (Table SF-11) indicates that the democratic peace is not due to the Cold War (Gowa 1999; McDonald 2015) or subject to other temporal shifts (Cederman 2001; Nieman 2016). ${ }^{26}$ In Table SF-12, our conclusions are robust to including various measures for contract-intensive economies as suggested in Mousseau (2000, 2009, 2013). In Table SF-13, we show that our results are robust to controlling for major parts of the "capitalist peace" argument in Gartke (2007). In Tables SF-14 and SF-15, we control for the proxies for stable borders that Gibler (2012) suggests are important confounding variables. In contrast to that study, the democratic peace remains strong when adding these to our preferred design.

\section{Conclusions}

Our findings from this article have led us to reevaluate the structural basis for the democratic peace. By theorizing three different accountability mechanisms - (1) the electoral, (2) the horizontal, and (3) the social-we are able to specify the institutional sources of dyadic democracy's ability to deter bellicose behavior. Specifically, we show that, when entered individually, all three mechanisms promote the democratic peace, when controlling for standard correlates of interstate disputes. When pitted against each other, however, we only find evidence consistent with support for the horizontal and social accountability mechanisms. Electoral accountability only works when social accountability is present. This finding is consistent with Maoz and Russett's $(1993,626)$ previously unverified claim that "the mobilization of ... general public opinion" matters at the same order of importance as the "variety of institutions that make up the system of government." Our findings on horizontal constraint are also consistent with the claims of earlier institutional explanations of the democratic peace such as Doyle's (1986) "liberal peace" argument and Choi's (2010) focus on legislative veto players. However, our results on the role of civil society are novel and consequent, suggesting that the importance of social mobilization has been undervalued theoretically as a source of audience cost and constraint. The exclusion of the pacificatory role of civil society in this literature may well be a function of the paucity of data to measure it prior to V-Dem. Given the 
strong model fit and predictive performance of the models that include this new VDem variable, this omission has been an important oversight in the literature from the perspective of a constraint-based theorization of the mechanisms behind the democratic peace.

At first sight, the policy implication of these findings would seem to be clear: in order to promote international security, it is not enough to strengthen electoral competitiveness or the quality of elections. Such measures should also include strengthening horizontal mechanisms of effective constraint on the executive, promotion of a more vibrant civil society that monitors and constrains those exercising executive power, or a combination of the two. If the goal is order in the international system, reforms that empower the legislative and judicial branches vis-à-vis the executive should not be neglected despite electoral reform, and the promotion of the initiatives of an organized and active citizenry in civil society should complement the strengthening of opposition political parties. However, inasmuch as democracy functions as an integrated whole, sufficient levels of electoral accountability cannot be easily discarded from a policy agenda to promote peace. While they cannot be neglected, they perhaps should not take precedence once democratic minimums are established. Most importantly, it cannot be ruled out that the promotion of electoral accountability is also a way of protecting or reinforcing the other accountability mechanisms. Students of judicial independence and oversight, for example, tend to stress the logic of the "insurance argument," which holds that competitiveness at the polls undergirds executive support for judicial constraints by creating uncertainty about the future prospects of staying in office (for an overview, see Vanberg 2015). Similarly, to the extent that the state can constrain and harass civil society, the strength of civil society is arguably not simply an independent source of constraint on its own but is guaranteed by the sort of robust competition at the polls that protects the freedoms of association and expression that civil society requires.

Despite our reticence to completely and precipitously reject the impact of electoral accountability, we still believe we have moved the democratic peace literature forward by stressing the greater relative importance of the nonelectoral mechanisms of accountability. The essence of constraint is preventing those who exercise executive power from acting in an arbitrary and ill-advised fashion, leading to destructive forms of interstate conflict. The electoral mechanism does determine who holds executive office, but its constraining power is time dependent, tied to the elections cycle. Both the less formal vertical constraining power of civil society and horizontal constraints posed by the countervailing powers of the legislative and judicial branches of government are not dependent on the timing of elections but consistent over time. This plausibly helps to explain why they are a more effective constraint on the kinds of arbitrary executive action that pose a threat to peace than the constraints posed by threat of losing office in the future.

Another important contribution of this article is its demonstration of potential uses of the V-Dem data in the study of conflict. Our findings demonstrate two of the 
comparative advantages of V-Dem over Polity. First, the V-Dem has a more explicit concept-to-measurement design. That allows us to examine other conceptualizations of democracy and the subcomponents of democratic systems in new and theoretically innovative ways. Second, the modular nature of V-Dem's aggregation procedures allows us to disaggregate democracy into its component parts, facilitating the operationalization of theoretical mechanisms in a much more precise fashion. This also means that the data set is also amenable to creating new aggregates from its components to match the concepts that researchers want to model. Accordingly, our fit tests show that our V-Dem-based indices model the democratic peace much better than Polity, both in terms of in-sample goodness of fit and out-of-sample predictive performance. Our specification is also much less sensitive than earlier studies to recent critiques of the democratic peace such as demonstrated in our robustness tests. To date, only a few papers have explored the utility of the V-Dem data for addressing questions in international relations, and our findings should serve as a demonstration of how the V-Dem data allow researchers to ask new questions whose exploration was not possible due to data constraints or to return to older questions with greater nuance.

\section{Authors' Note}

Earlier versions of the article have been presented to the 2016 convention of the International Studies Association, the 2016 Swedish National Conference on Peace and Conflict Research, and the 2016 convention of the American Political Science Association.

\section{Acknowledgments}

Thanks to Charity Butcher, Stephen Marr, Nils Petter Gleditsch, and Michael J. Reese for comments on earlier versions of the article and to Jennifer C. Boylan, Ryan P. Whittingham, Gudlaug Olafsdottir, and Kristina Petrova for excellent research assistance.

\section{Declaration of Conflicting Interests}

The author(s) declared no potential conflicts of interest with respect to the research, authorship, and/or publication of this article.

\section{Funding}

The author(s) disclosed receipt of the following financial support for the research, authorship, and/or publication of this article: The research has been funded by the Research Council of Norway, project 217995/V10, the University of Florida Foundation in support of the Raymond and Miriam Ehrlich Chair, Riksbankens Jubileumsfond, Grants P16-0124:1 and M13-0559:1, the European Research Council project H2020-ERC-2015-AdG 694640 (ViEWS), the Swedish Research Council, Grant 2012-5562, the Wenner-Gren Foundation, and the Fernand Braudel Senior Fellowship at the European University Institute, Florence.

\section{ORCID ID}

Håvard Hegre (D) https://orcid.org/0000-0002-5076-0994 


\section{Supplemental Material}

Supplemental material for this article is available online.

\section{Notes}

1. Supplemental material for this article are also available at http://views.pcr.uu.se/ downloads

2. Other explanations are reviewed in Hegre (2014). These include the argument that democracies are better able to mobilize resources in war (Reiter and Stam 1998), or to form alliances (Doyle 1986), or that they have joint interests in international relations (Gartzke 1998). The Varieties of Democracy (V-Dem) data set is not well suited to shed more light on these particular arguments.

3. The results in Schultz (1999) and Prins (2003) are more in line with the signaling argument than the constraints explanation whereas Weeks (2008) shows that singleparty regimes also behave in line with a signaling argument. Snyder and Borghard (2011), Downes and Sechser (2012), and Trachtenberg (2012) do not support the audience cost argument.

4. Dahl's (1971) influential model of "Polyarchy" is a more maximalist version of electoral democracy that also brings in more extensive political rights and civil liberties. In our effort to tease out what specific mechanisms help explain the democratic peace, we rely on the more minimalist conception.

5. In Section 2 in the SF, we provide a concrete illustration of how popular protest can affect the behavior of democratic states.

6. Such "Potemkin village" organizations are different from the astroturf organizations that exist in some democracies. Astroturf organizations are sponsored by corporations to seem like real grassroots citizens' initiatives. Potemkin village organizations are sponsored by the state to serve the interests of the state. While astroturf organizations engage in deception and contribute to unequal access in established democracies, they do represent concrete interests rather than masquerading as them to promote the interests of the state.

7. Several earlier studies relied on other, dichotomous indicators of democracy (e.g., Babst 1964; Small and Singer 1976; Doyle 1986), and Rummel (1983) used the Freedom House data.

8. We discuss the limitations of Polity in Section 3 in the SF. Disaggregation using Polity is not feasible due the noncorrespondence between its conceptualization and the components of democracy we need to do our analysis.

9. We embarked on this project long before the release of version 8 of V-Dem, the first version which goes back to 1789 .

10. We use the V-Dem labels for these indicators. See the V-Dem codebook (Coppedge et al. 2016a) for details.

11. If $v 2 x \_l$ legcon is missing information, we assume the legislature is missing entirely and set v2x_legcon to 0 .

12. In Table SF-7, we also report models entering the legislative and judicial constraints separately as well as a media freedom index. The results are very similar to those in the 
preferred specification. Table 2 below also shows the goodness-of-fit statistics for these models. The model using the combined executive constraint performs better than the individual indices.

13. If v2x_cspart is missing information, we imputed the value based on the v2cscnsult, $\mathrm{v} 2 \mathrm{csprtcpt}$, and $\mathrm{v} 2 \mathrm{csgender}$ indicators.

14. For earlier years, these correlations are considerably lower.

15. The indices for each country have increased somewhat over the period, but in aggregate, these trends were counteracted by the entry of new and less democratic political systems following decolonialization.

16. Consequently, in 1930 none of the political systems that Polity give the maximum score of 10 is given a V-Dem Polyarchy score above 0.84 . In 2012, countries that Polity regard as maximally democratic obtain a score of 0.89 on average (see Figure SF-4). There is still considerable variation among what Polity codes as close to maximally democratic. France, the US, and the UK score high on the Polyarchy index, whereas Hungary and Israel have relatively low scores.

17. The mean here is the average value for the index across all countries for all years 1900 to 2010. All other variables are assumed to have values zero.

18. That we have plotted the democracy score of the stronger country along the $x$-axis rather than that of the weaker country is inconsequential — plots where the stronger and weaker country switch place look very similar.

19. Complete estimation results in table form with all control variables are found in Table SF3 , column 4.

20. See Section 4 in the SF for a discussion of these issues. The random measurement error should also overall be smaller for electoral accountability since it, unlike the other two indices, is partly based on factual (as opposed to expert-coded) indicators. This then also cannot explain why electoral accountability has a smaller impact on peace.

21. See Ward, Greenhill, and Bakke (2010) for an argument for why this is a necessary complement to standard significance testing.

22. The results from this asymmetrically reduced model are shown in Table SF-8. Only the intercept terms change substantially compared to the full-sample results in Table SF-3.

23. This result is in line with the studies on "political similarity" (Peceny, Beer, and SanchezTerry 2002; Raknerud and Hegre 1997).

24. The predicted change in log odds due to the electoral accountability model (the sum $\beta_{1} x_{i}$ $+\beta_{2} x_{j}+\beta_{3} x_{i j}$ ) is 2.05 for GBR-PRK and 1.19 for GBR-MMR. The predicted odds ratio is 2.36, the exponential of the difference between these two. Since these are rare events, the ratio of predicted probabilities is very close to this figure.

25. The strengthening effect of democratic institutions emerges much more clearly here than in previous studies using Polity since V-Dem is superior in discerning improvements in the quality of democracy (see Figure SF-4).

26. Note that these studies do not agree on the periods in which the democratic peace is particularly strong or weak. 


\section{References}

Altman, David. 2010. Direct Democracy Worldwide. Cambridge, MA: Cambridge University Press.

Arato, Andrew. (1981) 1993. "Civil Society and the State, Poland 1980-81." In From NeoMarxism to Democratic Theory, 71-211. Armonk, NY: M.E. Sharpe.

Babst, Dean V. 1964. "Elective Governments - A Force for Peace." The Wisconsin Sociologist 3 (1): 9-14.

Barber, Benjamin. 1984. Strong Democracy: Participatory Politics for a New Age. Berkeley: University of California Press.

Bennett, Scott D. 2006. "Toward a Continuous Specification of the Democracy-autocracy Connection.” International Studies Quarterly 50 (2): 313-38.

Bremer, Stuart A. 1992. "Dangerous Dyads: Conditions Affecting the Likelihood of Interstate War, 1816-1965." Journal of Conflict Resolution 36 (2): 309-41.

Bueno de Mesquita, Bruce, James D. Morrow, Randolph M. Siverson, and Alastair Smith. 1999. “An Institutional Explanation of the Democratic Peace." American Political Science Review 93 (4): 791-807.

Bueno de Mesquita, Bruce, Randolph M. Siverson, and Gary Woller. 1992. "War and the Fate of Regimes: A Comparative Analysis.” American Political Science Review 86 (3): 638-46.

Cederman, Lars-Erik. 2001. "Back to Kant: Reinterpreting the Democratic Peace as a Macrohistorical Learning Process.” American Political Science Review 93 (4): 791-808.

Chalmers, Douglas A., Scott B. Martin, and Kerianne Pister. 1997. “Associative Networks: New Structures of Representation for the Popular Sectors?" In The New politics of Inequality in Latin America: Rethinking Participation and Representation, edited by Douglas A. Charlmers, Carlos M. Vilas, Katherine Hite, Scott B. Martin, Kerianne Piester, and Monique Segarra, 543-82. Oxford, UK: Oxford University Press.

Choi, Seung-Whan. 2010. "Legislative Constraints: A Path to Peace?" Journal of Conflict Resolution 54 (3): 438-70.

Choi, Seung-Whan. 2013. "The Democratic Peace through an Interaction of Domestic Institutions and Norms: Executive Constraints and Rule of Law." Armed Forces and Society 39 (2): 255-83.

Clark, David H., and Timothy Nordstrom. 2005. "Democratic Variants and Democratic Variance: How Domestic Constraints Shape Interstate Conflict." The Journal of Politics 67 (1): 250-70.

Coppedge, Michael, John Gerring, Staffan Lindberg, Svend-Erik Skaaning, Jan Teorell, David Altman, and Michael Bernhard. et al. 2016a. Varieties of Democracy (V-Dem). Codebook v6. Göteborg, Sweden: V-Dem Institute. Accessed June 15, 2017. https://www. v-dem.net/media/filer_public/d1/24/d124efd5-7ff5-4175-a1ed-f294984084d0/v-dem_ codebook_v6.pdf.

Coppedge, Michael, John Gerring, Staffan I. Lindberg, Svend-Erik Skaaning, Jan Teorell, David Altman, and Michael Bernhard. et al. 2016b. V-Dem Country-Year Dataset v6. Varieties of Democracy (V-Dem) Project. Accessed June 15, 2017. https://www.v-dem. net/en/data/data-version-6/. 
Coppedge, Michael, John Gerring, Staffan I. Lindberg, Svend-Erik Skaaning, Jan Teorell, Frida Andersson, and Kyle Marquardt. et al. 2016c. V-Dem Methodology v6. Varieties of Democracy (V-Dem) Project. Accessed June 15, 2017. https://www.v-dem.net/files/42/ Methodology\%20v6.pdf.

Cornell, Agnes, and Marcia Grimes. 2015. "Institutions as Incentives for Civic Action: Bureaucratic Structures, Civil Society, and Disruptive Protests." The Journal of Politics 77 (3): 664-78.

Dahl, Robert A. 1971. Polyarchy: Political Participation and Opposition. New Haven, CT: Yale University Press.

Dalton, Russell J., Susan E. Scarrow, and Bruce E. Cain. 2003. "New Forms of Democracy? Reform and Transformation of Democratic Institutions." In Democracy Transformed? Expanding Political Opportunities in Advanced Industrial Democracies, edited by Bruce E. Cain, Russell J. Dalton, and Susan E. Scarrow, 1-22. Oxford, UK: Oxford University Press.

Dixon, William J. 1994. "Democracy and the Peaceful Settlement of International Conflict." American Political Science Review 88 (1): 1-17.

Downes, Alexander B., and Todd S. Sechser. 2012. "The Illusion of Democratic Credibility." International Organization 66 (3): 457-89.

Doyle, Michael W. 1986. "Liberalism and World Politics." American Political Science Review 80 (4): 1151-69.

Edwards, Bob, and Robert W. Foley. 1999. "Civil Society and Social Capital beyond Putnam." American Behavioral Scientist 42 (1): 124-39.

Ekiert, Grzegorz, and Jan Kubik. 1999. Rebellious Civil Society, Popular Protest and Democratic Consolidation in Poland. Ann Arbor: University of Michigan Press.

Ember, Carol R., Melvin Ember, and Bruce M. Russett. 1992. "Peace between Participatory Polities: A Cross-cultural Test of the 'Democracies Rarely Fight Each Other' Hypothesis." World Politics 44 (4): 573-99.

Fearon, James D. 1994. "Domestic Political Audiences and the Escalation of International Disputes." American Political Science Review 88 (3): 577-92.

Fearon, James D. 1995. "Rationalist Explanations for War." International Organization 49 (3): 379-79.

Fung, Arshon, and Erik Olin Wright. 2003. "Countervailing Power in Empowered Participatory Governance." In Deepening Democracy: Institutional Innovation in Empowered Participatory Governance, edited by Arshon Fung and Erik Olin Wright, 259-90. London, UK: Verso.

Gartzke, Erik. 1998. "Kant We All Just Get Along? Opportunity, Willingness, and the Origins of the Democratic Peace." American Journal of Political Science 42 (1): 1-27.

Gartzke, Erik. 2007. "The Capitalist Peace.” American Journal of Political Science 51 (1): 166-91.

Gat, Azar. 2006. War in Human Civilization. Oxford, UK: Oxford University Press.

Gibler, Douglas M. 2012. The Territorial Peace: Borders, State Development and International Conflict. Cambridge, MA: Cambridge University Press. 
Gleditsch, Nils Petter, Steven Pinker, Bradley A Thayer, Jack S. Levy, and William R. Thompson. 2013. "The Forum: The Decline of War." International Studies Review 15: 396-419.

Gould, Carol. 1988. Rethinking Democracy: Freedom and Social Cooperation in Politics, Economy and Society. Cambridge, UK: Cambridge University Press.

Gowa, Joanne. 1999. Ballots and Bullets: The Elusive Democratic Peace. Princeton, NJ: Princeton University Press.

Grimes, Marcia. 2013. "The Contingencies of Societal Accountability: Examining the Link Between Civil Society and Good Government." Studies in Comparative International Development 48 (4): 380-402.

Hegre, Håvard. 2008. "Gravitating toward War. Preponderance May Pacify, but Power Kills." Journal of Conflict Resolution 52 (4): 566-89.

Hegre, Håvard. 2009. "Trade Dependence or Size Dependence?: The Gravity Model of Trade and the Liberal Peace." Conflict Management and Peace Science 26 (1): 26-45.

Hegre, Håvard. 2014. "Democracy and Armed Conflict." Journal of Peace Research 51 (2): 159-72.

Hegre, Håvard, John R. Oneal, and Bruce Russett. 2010. "Trade Does Promote Peace: New Simultaneous Estimates of the Reciprocal Effects of Trade and Conflict." Journal of Peace Research 47 (6): 763-74.

Hermet, Guy, Richard Rose, and Alain Rouquie. 1978. Elections without Choice. London, UK: Palgrave Macmillan.

Houtzager, Peter P., and Adrian Gurza Lavalle. 2010. "Civil Society's Claims to Political Representation in Brazil." Studies in Comparative International Development 45 (1): 1-29.

Jann, Ben. 2014. "Plotting Regression Coefficients and Other Estimates." Stata Journal 17: 708-37.

Kant, Immanuel. (1795) 1991. "Perpetual Peace: A Philosophical Sketch.” In Kant: Political Writings, edited by Hans Reiss, 93-130. Cambridge, MA: Cambridge University Press.

Keck, Margaret, and Kathryn Sikkink. 1998. Activists beyond Borders, Advocacy Networks in International Politics. Ithaca, NY: Cornell University Press.

Kuran, Timur. 1991. "Now Out of Never: The Element of Surprise in the East European Revolution of 1989." World Politics 44 (1): 7-48.

Lindberg, Staffan I. 2013. "Mapping Accountability: Core Concept and Subtypes." International Review of Administrative Sciences 79 (2): 202-26.

Lindberg, Staffan I., Michael Coppedge, John Gerring, Jan Teorell, Daniel Pemstein, Eitan Tzelgov, and Yi-ting Wang. et al. 2014. "V-Dem: A New Way to Measure Democracy." Journal of Democracy 25 (3): 159-69.

Lohmann, Susanne. 1994. "Dynamics of Informational Cascades: The Monday Demonstrations in Leipzig, East Germany, 1989-1991.” World Politics 47 (1): 42-101.

McAdam, Doug, and Sidney Tarrow. 2010. "Ballots and Barricades: On the Reciprocal Relationship between Elections and Social Movements." Perspectives on Politics 8 (2): 529-42.

McDonald, Patrick J. 2015. "Great Powers, Hierarchy, and Endogenous Regimes: Rethinking the Domestic Causes of Peace.” International Organization 69 (3): 557-88. 
Macpherson, C. B. 1977. The Life and Times of Liberal Democracy. Oxford, UK: Oxford University Press.

Maoz, Zeev. 2005. Dyadic MID Dataset (version 2.0). Accessed June 15, 2017. http://vanity. dss.ucdavis.edu/ maoz/dyadmid.html.

Maoz, Zeev, and Bruce M. Russett. 1993. "Normative and Structural Causes of Democratic Peace, 1946-1986." American Political Science Review 87 (3): 624-38.

Marshall, Monty G.2014. "Polity IV Project: Political Regime Characteristics and Transitions, 1800-2009.” Accessed January 16, 2014. http://www.systemicpeace.org/polity/ polity4.htm.

Merkel, Wolfgang. 2004. "Embedded and Defective Democracies." Democratization 11 (5): 33-58.

Mousseau, Michael. 2000. "Market Prosperity, Democratic Consolidation, and Democratic Peace." Journal of Conflict Resolution 44 (4): 472-507.

Mousseau, Michael. 2009. "The Social Market Roots of Democratic Peace." International Security 33 (4): 52-86.

Mousseau, Michael. 2013. "The Democratic Peace Unraveled: It's the Economy." International Studies Quarterly 57 (1): 186-97.

Munck, Gerardo L. 2009. Measuring Democracy: A Bridge between Scholarship and Politics. Baltimore, MD: Johns Hopkins University Press.

Nieman, Mark David. 2016. "Moments in Time: Temporal Patterns in the Effect of Democracy and Trade in Conflict." Conflict Management and Peace Science 33 (3): 273-93.

O’Donnell, Guillermo. 1994. "Delegative Democracy.” Journal of Democracy 5 (1): 55-69.

O’Donnell, Guillermo. 1998. "Horizontal Accountability in New Democracies." Journal of Democracy 9 (3): 112-26.

O’Donnell, Guillermo, and Philippe Schmitter. 1986. "Tentative Conclusions about Uncertain Democracies." In Transitions from Authoritarian Rule, Vol. 4, edited by Guillermo O'Donnell, Phillippe Schmitter, and Laurence Whitehead, 1-72. Baltimore, MD: Johns Hopkins.

Palmer, Glenn, Vito d'Orazio, Michael Kenwick, and Matthew Lane. 2015. "The MID4 Dataset: Procedures, Coding Rules and Description." Conflict Management and Peace Science 32 (2): 222-42.

Pateman, Carole. 1970. Participation and Democratic Theory. Cambridge, UK: Cambridge University Press.

Peceny, Mark, Caroline C. Beer, and Shannon Sanchez-Terry. 2002. "Dictatorial Peace." American Political Science Review 96 (1): 15-26.

Pemstein, Daniel, Kyle L. Marquardt, Eitan Tzelgov, Yi-ting Wang, and Farhad Miri. 2015. "The V-Dem Measurement Model: Latent Variable Analysis for Cross-National and Cross-Temporal Expert-Coded Data.” V-Dem Institute Working Paper Series 2015: 21, December 2015. Accessed June 15, 2017. https://ssrn.com/abstract=2613421.

Petterson, Therése, and Kristine Eck. 2018. “Organized Violence, 1989-2017.” Journal of Peace Research 55 (4): 535-47. 
Prins, Brandon. 2003. "Institutional Instability and the Credibility of Audience Costs: Political Participation and Interstate Crisis Bargaining, 1816-1992." Journal of Peace Research 40 (1): 67-84.

Przeworski, Adam, Susan C. Stokes, and Bernard Manin. 1999. Democracy, Accountability and Representation. Cambridge, UK: Cambridge University Press.

Pinker, Steven. 2011. The Better Angels of Our Nature. Why Violence has Declined. New York, NY: Viking.

Putnam, Robert. 1993. Making Democracy Work. Civic Traditions in Modern Italy. Princeton, NJ: Princeton University Press.

Raknerud, Arvid, and Håvard Hegre. 1997. "The Hazard of War: Reassessing the Evidence for the Democratic Peace." Journal of Peace Research 33 (4): 385-404.

Reiter, Dan, and Allan C. Stam. 1998. "Democracy, War Initiation, and Victory." American Political Science Review 92 (2): 377-89.

Reiter, Dan, and Erik R. Tillman. 2002. "Public, Legislative, and Executive Constraints on the Democratic Initiation of Conflict." Journal of Politics 64 (3): 810-26.

Robertson, Graeme B. 2011. The Politics of Protest in Hybrid Regimes. Cambridge, UK: Cambridge University Press.

Rosato, Sebastian. 2003. "The Flawed Logic of Democratic Peace Theory." American Political Science Review 97(4): 585-602.

Rummel, Rudolph J. 1983. "Libertarianism and International Violence." Journal of Conflict Resolution 27 (1): 27-71.

Schedler, Andreas. 1999. "Conceptualizing Accountability." In The Self-Restraining State: Power and Accountability in New Democracies, edited by Andreas Schedler, Larry Diamond, and Marc Plattner, 13-28. Boulder, CO: Lynne Rienner.

Schultz, Kenneth A. 1999. "Do Democratic Institutions Constrain or Inform? Contrasting Two Institutional Perspectives on Democracy and War." International Organization 53 (2): 233-66.

Schumpeter, Joseph. [1942] 2003. Capitalism, Socialism and Democracy. London, UK: Routledge.

Schweller, Randall L. 1992. "Domestic Structure and Preventive War: Are Democracies More Pacific?" World Politics 44 (2): 235-69.

Singer, J. David, Stuart Bremer, and John Stuckey. 1972. "Capability Distribution, Uncertainty, and Major Power War, 1820-1965." In Peace, War, and Numbers, edited by Bruce M. Russett, 19-48. Beverly Hills, CA: Sage.

Small, Melvin, and J. David Singer. 1976. "The War-Proneness of Democratic Regimes, 1816-1965." Jerusalem Journal of International Relations 1 (4): 50-69.

Smulovitz, Catalina, and Enrique Peruzzotti. 2000. "Societal Accountability in Latin America." Journal of Democracy 11 (4): 147-58.

Snyder, Jack, and Erica D. Borghard. 2011. "The Cost of Empty Threats: A Penny, Not a Pound." American Political Science Review 105:437-56.

Stepan, Alfred. 1985. "State Power and the Strength of Civil Society in the Southern Cone of Latin America." In Bringing the State Back In, edited by Peter B. Evans, Dietrich Rueschemeyer, and Theda Skocpol, 317-46. Cambridge, MA: Cambridge University Press. 
Tomz, Michael, Jason Wittenberg, and Gary King. 2003. "CLARIFY: Software for Interpreting and Presenting Statistical Results.” Journal of Statistical Software. Accessed June 15, 2017. http://j.mp/k3k0rx.

Trachtenberg, Marc. 2012. “Audience Costs: An Historical Analysis.” Security Studies 21 (1): 3-42.

Vanberg, Georg. 2015. "Constitutional Courts in Comparative Perspective: A Theoretical Assessment." Annual Review of Political Science 18:167-85.

Ward, Michael D., Brian D. Greenhill, and Kristin M. Bakke. 2010. "The Perils of Policy by P-value: Predicting Civil Conflicts." Journal of Peace Research 47 (4): 363-75.

Weeks, Jessica L. 2008. "Autocratic Audience Costs: Regime Type and Signaling Resolve". International Organization 62 (1): 35-64.

Weiss, Jessica L. 2014. Powerful Patriots: Nationalist Protest in China's Foreign Relations. New York: Oxford University Press.

Welzel, Christian, Ronald F. Inglehart, and Franziska Deutsch. 2005. "Social Capital, Voluntary Associations and Collective Action: Which Aspects of Social Capital Have the Greatest 'Civic' Payoff?” Journal of Civil Society 1 (2): 121-46.

Werner, Suzanne. 2000. "The Effects of Political Similarity on the Onset of Militarized Disputes, 1816-1985." Political Research Quarterly 53 (2): 343-74.

Zelner, Bennet A. 2009. "Using Simulation to Interpret Results from Logit, Probit, and Other Nonlinear Models.” Strategic Management Journal 30:1335-48. 